\title{
Przed. Notatki na marginesach książki Piotra Szaroty Wiedeń 1913
}

\section{Before. Notes on the margins of Piotr Szarota's book Wiedeń 1913}

\author{
Katarzyna Kuczyńska-Koschany \\ Uniwersytet im. Adama Mickiewicza
}

\begin{abstract}
The article is a wide, contextual and open attempt on the educational actions at a review of the book Wieden 1913 written by Piotr Szarota. The author proposes lecture based on the category of "before", this concept deconstructs the idea of "good old times", it questions the "ubi sunt" theme. In other words: the conviction that Szarota creates critical vision of Vienna's spacetime of the year before the World War I leads author of the review to emphatic as well as critical lecture of the book Wieden 1913.

Key words: World War I, Vienna, anticipation, 19th century, 20th century, Danube Monarchy

Streszczenie: Artykuł jest próbą omówienia - szerokiego, kontekstowego i interpretacyjnie otwartego na działania edukacyjne - książki Piotra Szaroty pt. Wiedeń 1913. Autorka proponuje koncept lekturowy oparty na kategorii „przed”, dekonstruujący pojęcie „dawnych, dobrych czasów”, kwestionujący topos „ubi sunt”. Innymi słowy: przekonanie, iż Szarota krytycznie czyta wiedeńską czasoprzestrzeń roku poprzedzającego wybuch I wojny światowej, skłania autorkę omówienia do zarówno empatycznej, jak krytycznej lektury książki Wiedeń 1913.
\end{abstract}

Słowa kluczowe: I wojna światowa, Wiedeń, antycypacja, wiek XIX, wiek XX, monarchia naddunajska

Przed wojną nigdy nie wiemy, że to jest czas przed wojną, ostatnie chwile. Niedawno nikt (albo prawie nikt) nie wyobrażał jej sobie na Ukrainie ani w Syrii. Wyobrazić sobie „przed” bez besserwisserskiego „po” (pytania: „dlaczego szybko nie brali ślubu?”, „dlaczego nie wyjechali zawczasu?”, "dlaczego nie wypłacili wszystkich pieniędzy i nie uciekli?"), wykrzesać z siebie wiedzę, iż wojna zawsze przychodzi w samym środku pokoju - to wymaga naprawdę sporego wysiłku imaginacyjnego. Książka Piotra Szaroty, którą staram się tu omówić, daje duże możliwości w tak pomyślanej, twórczej i wywołującej refleksję uczniów, edukacji polonistycznej. 
Piotr Szarota pisze swą książkę o Wiedniu przed Wielką Wojną, o jego bogactwie i nadmiarze, jakby zaczytany w bajce Zbigniewa Herberta pt. Od końca (z tomu Hermes, pies i gwiazda), Herberta, urodzonego w bardzo austro-węgierskim, galicyjskim Lwowie, autora ironicznego wobec wiedeńskich koncepcji obecności Słowian w monarchii naddunajskiej wiersza Mitteleuropa (z tomu Rovigo) i afirmatywnego wobec kultury śródziemnomorskiej „na krańcach imperium” eseju Lekcja łaciny (z tomu Labirynt nad morzem; Herbert 2000, 165-197). Przypomnę tę bajkę, która patronuje moim zdaniem - tomowi Szaroty, zwłaszcza jego konstrukcji, chociaż przypomina również kompozycję pisanych po Holokauście próz: Zagłady Piotra Szewca i Badenheim 1939 Aharona Appelfelda ${ }^{1}$ :

A potem ustawiono wielki stół i odbyła się wspaniała weselna uczta. Księżniczka była tego dnia jeszcze piękniejsza niż zwykle. Grała muzyka. Dziewczęta śliczne jak księżyce tańczyły na dole.

No dobrze, ale co było przedtem? Ach, nie myślmy nawet o tym. Czarna wróżka bije o okna jak ćma. Czterdziestu rozbójników pogubiło w ucieczce długie noże i brody, a smok zamieniony w chrabąszcza śpi spokojnie na liściu migdału (Herbert 2008, 201).

Właśnie, wydaje się, iż Szarota pisze i po Wielkiej Wojnie, i po Zagładzie. Te są nierozdzielne. Dlatego, być może, czeski filozof Jan Patočka w eseju pod znaczącym tytułem Wojna XX wieku oraz wiek XX jako wojna ${ }^{2}$ przenikliwie konstatował:

Pierwsza wojna jest wydarzeniem rozstrzygającym w historii XX wieku. Zadecydowała ona o całym jego charakterze. Właśnie ona ukazała, że przemiana świata w laboratorium uruchamiające zasoby energii akumulowanej przez miliardy lat musi się dokonywać w formie wojny. Dlatego wojna ta oznaczała ostateczny przełom w pojmowaniu bytu zapoczątkowanym w XVII wieku przez mechanicystyczne przyrodoznawstwo oraz likwidację wszystkich tych „konwencji”, które dla tego wyzwalania sił stanowiły przeszkodę - przewartościowanie wszelkich wartości pod znakiem siły (Patočka 1998, 170-171).

Pierwsza wojna, katastrofa pierworodna naszego stulecia (Stern 2001), wywołuje - jak grzech pierworodny w micie biblijnym - następne katastrofy: totalitaryzmy hitlerowski i stalinowski, drugą wojnę światową, Zagładę Żydów. Rozdział Tenebrae. Europa podczas zaćmienia w monumentalnym dziele historyka, Normana Daviesa, nosi daty 1914-1945 (Davies 1999, 955-1123). Ta konstrukcja z Herberta, związana z pytaniem: „no dobrze, ale co było przedtem?” - jest więc głęboka. Ma ona także swą przeciw-konstrukcję, znakomicie opisaną w szkicu Ewy Wiegandt, autorki książki Austria felix, czyli o micie Galicji w polskiej prozie współczesnej, szkicu zatytułowanym Po (Wiegandt 2010, 8-16).

\footnotetext{
1 Aharon Appelfeld urodził się w Czerniowcach na Bukowinie, zatem także na rubieżach monarchii austro-węgierskiej.

Cytuję w przekładzie Juliusza Zychowicza.
} 
Piszę o tym wszystkim, przywołując głosy filozofa, historyków i literaturoznawczyni, gdyż lektura książki Piotra Szaroty jest kontaminacją owego złego baśniowego „przed” (Herberta) z innym, zbyt dobrym „przed”. Tak dotychczas pisano o tym, co było przed II wojną światową i przed Zagładą (to swego rodzaju topos, żydowski i polski jednocześnie; nie tylko Szewc i Appelfeld go podejmują; w każdym wspomnieniu lata 1939 dominuje jego niezwykłe ciepło i piękno - „A lato było piękne tego roku” - pisał Konstanty Ildefons Gałczyński w Pieśni o żołnierzach z Westerplatte).

Szarotę interesuje cały rok 1913, stąd podział nadmiaru zdarzeń i osób dramatu (które skądinąd nie wiedzą, że są osobami dramatu i że żyją w czasie „przed” katastrofą) na miesiące, jest nieco arbitralny, dzięki niemu jednak dyskurs otwiera się na skojarzenia i dygresje. Ważne, że nagle zdajemy sobie sprawę z bogactwa, ale też z zachowawczości Wiednia tuż przed Wielką Wojną. Czas stolicy monarchii naddunajskiej właśnie się kończy. Artyści uciekają do Berlina i Paryża, do Budapesztu i Monachium. Sama monarchia niebawem się rozpadnie, a jeszcze w trakcie wojny, nazwanej później - ex post - pierwszą światową, umrze widomy znak jej trwania, jej najbardziej czytelny symbol osobowy: cesarz Franciszek Józef I (zm. 21 listopada 1916 roku).

Wiedeń, można by tak rzec, swobodnie parafrazując Szekspira z jego Wieczoru trzech króli, „skonał od przesytu”. Dlatego na początku książki, jak na początku dzieła dramatycznego, wymienione są „OSOBY” (które mieszkają w Wiedniu bądź odwiedzają to miasto w roku 1913). Te najbardziej znane: Hermann Broch, nobliści Elias Canetti i Albert Einstein, Zygmunt Freud, Adolf Hitler, Franz Kafka, malarze Oskar Kokoschka i Egon Schiele, Robert Musil, Karl Kraus, Georg Trakl i Stefan Zweig, filozofowie Karl Popper i Ludwig Wittgenstein, Józef Stalin i Lew Trocki, kompozytorzy Karol Szymanowski i Anton von Webern. I te, które mamy - być może dopiero dzięki tej książce - odkryć: Peter Altenberg, „ikoniczna postać wiedeńskiej bohemy, znana z oryginalnego sposobu ubierania się i bezkompromisowych poglądów" (Szarota 2013, 7); Lou Andreas-Salomé, psychoanalityczka, pisarka, emancypantka, inspirująca kochanka Nietzschego i Rilkego; Richard Coudenhove-Kalergi, „twórca idei zjednoczenia Europy "od Polski po Portugalię”, prawnuk Marii Kalergis (ukochanej Norwida)” (Szarota 2013, 7); Bronisława Koller, secesjonistka wiedeńska, „uważana za jedną z najwybitniejszych artystek tamtego czasu" (Szarota 2013, 8); Alma Mahler-Werfel, „znana jako wiedeńska muza i femme fatale” (Szarota 2013, 8), Rosa Mayreder, pisarka feministyczna, która napisała książkę pt. Płeć i kultura, wybitną odpowiedź na dzieło Weiningera Płeć i charakter; zapoznana pokojowa noblistka z roku 1905, pacyfistka, Bertha von Suttner. I wreszcie, jak podaje autor książki, a może raczej reżyser szczególnej wiedeńskiej partytury, tego jedynego w swoim rodzaju theatrum mundi: „PONADTO WYSTĘPUJĄ DUCHY” - „Zmarłego w 1911 wybitnego 
kompozytora i dyrygenta Gustava Mahlera oraz nieżyjącego od 1903 filozofa Ottona Weiningera, autora czytanego w całej Europie bestselleru Płeć i charakter" (Szarota 2013, 9).

Piotr Szarota pisze o wiedeńczykach z przypadku i z urodzenia, o wiedeńczykach różnych narodowości, o tych, którzy nigdy Wiednia nie polubili i byli tam jedynie przejazdem albo z konieczności, jak Szymanowski czy Kafka. Od podszewki opisał autor omawianej książki Wiedeń przedpierwszowojenny, że dopisał komplementarny apokryf do znakomitego studium Ewy Kuryluk Wiedeńska apokalipsa. Kuryluk zbadała artystyczne przeczucia nadchodzącej wojny, Szarota - zachowania powszechne, artystów nie pomijając i czyniąc jedną z głównych bohaterek aurę Wiednia-rok-przed.

Zapisuję tutaj notatki na marginesach, bo tę książkę czyta się, gryzmoląc ołówkiem, tyle uruchamia się skojarzeń. Ma się ochotę kartkować pięknie wydany granatowy tom, z obrazem Klimta naklejonym na ciemność, antycypować lekturę zaglądaniem $\mathrm{w}$ niegdysiejsze portrety i fotografie, utrzymane $\mathrm{w}$ zupełnie wczorajszej manierze. Wiele rzeczy pozostało jednak w charakterze Wiednia do dzisiaj. Byłam wiedeńską stypendystką zimą 1999 roku, potwierdzam opinię Tadeusza Rittnera z roku 1913 o „jakiejś biernej, uśmiechniętej gościnności" tego miasta - po dwu światowych wojnach i Zagładzie!

Wszystkie książki, bardziej faktograficzne albo bardziej fikcjonalne, które próbują pokazać świat przed wielką wojną czy przed katastrofą, przedstawiają bezrefleksyjność i bezradność ludzi wtedy żyjących, ich fajerwerki. Podobnie było z I wojną światową: Lew Trocki pisał przenikliwe sprawozdania z pierwszej wojny bałkańskiej; najbardziej uważni wyczuwali zagrożenie, gdy na ulicach Wiednia pojawiły się napisy „Alle Serben müssen sterben”. „Sami wiedeńczycy nie byli jednak specjalnie przejęci” pisze Szarota, i by lepiej oddać aurę beztroski przed-katastrofalnej, cytuje świadka epoki, Stefana Zweiga i jego Świat wczorajszy:

Pośpiech nie tylko uchodził za nieelegancki, ale rzeczywiście był niepotrzebny, gdyż w tym po mieszczańsku ustabilizowanym świecie, zabezpieczonym na wszystkie strony, nic nie zdarzało się nagle. Jeśli następowały katastrofy, to gdzieś daleko, na krańcach świata, i nic z nich nie przenikało przez dobrze izolowane ściany „bezpiecznego” życia. Wojna z Burami, wojna japońsko-rosyjska, nawet wojna na Bałkanach nie docierały w ogóle do świadomości moich rodziców.

Przeglądali komunikaty wojenne w gazecie równie obojętnie jak rubrykę sportową (Szarota 2013, 21, podkreśl. KKK).

Warto być może przeczytać te słowa - bardzo uważnie - dzisiaj, bo świat dzisiejszy nie różni się od świata wczorajszego i, niestety, złudzenia co do odległości katastrof też się nie różnią. Zatem lektura tego świata, kawiarniano-teatralnego, zajętego samym sobą, oscyluje pomiędzy przestrogą a nostalgią. Czasem bliżej przestrogi. Bo w mieście niepoliczalnych stolików kawiarnianych i dwustu tytułów prasowych, wydawanych we wszystkich językach monarchii, Stalin na polecenie Lenina, właśnie w roku 1913, 
pisze studium Marksizm a kwestia narodowa, czyli „projekt ZSRR jako więzienia narodów, projekt, który kilka lat później udało się wcielić w życie z przerażającą precyzją" (Szarota 2013, 30).

Przed I wojną światową - to nie bajka - Adolf Hitler (który powtarzał klasę) i Ludwig Wittgenstein (który poszedł do szkoły rok wcześniej) chodzili razem do szkoły. Dzieliły ich nie tylko dwa lata, dzieliło ich wszystko. Pierwszy miał przekształcić niemczyznę w język oprawców, począwszy od Mein Kampf, gdzie wspomina „żydowskiego chłopca” z Linzu, wobec którego zachowywał dystans (Szarota 2013, 33). Drugi miał zostać największym filozofem języka w XX wieku, a jego słynna formuła, mówiąca, iż „granice mojego języka są granicami mojego świata”, określa równie dobrze wybitny umysł myśliciela, co granice świata wyznaczone przez Hitlera, szkolnego kolegę.

Istnieje jeszcze, tam i wtedy, pojęcie skandalu, które nie dotyczy ludobójstwa czy zbiorowego gwałtu, ale koncertu. Tak było z pamiętnym koncertem Arnolda Schönberga w roku 1913, podczas którego twórcę muzyki atonalnej odsyłano głośno do Steinhof (słynnego pobliskiego zakładu psychiatrycznego). Tak było z wystawą młodych malarzy, o których następca tronu, Franciszek Ferdynand, wyrokował „Schweinerei!”, więc Klimt czy Schiele woleli wystawiać w Monachium czy Budapeszcie niż w zachowawczym Wiedniu.

Edukacja w Wiedniu - tuż przed Wielką Wojną? To może nas szczególnie interesować. I tu trzeba przywołać hasło THERESIANUM, szkoła ufundowana dla szlacheckiej młodzieży przez cesarzową Marię Teresę w 1746 roku, by kształcić przyszłych pracowników państwowej służby administracyjnej (także znanych Polaków: Henryka Rodakowskiego, Kazimierza Twardowskiego czy Tadeusza Rittnera). Dla jednych szkoła, do której wracają z nostalgią, dla drugich - niewola, z której wychodzi się na wolność. Do tych pierwszych należał posługujący się antysemicką retoryką przyszły wieloletni burmistrz Wiednia, Karl Lueger, autor książki Kampf und Europa. Wśród absolwentów odmiennie myślących trzeba koniecznie wymienić Roberta Musila, który sportretował tę koszmarną edukację w swych słynnych Niepokojach wychowanka Törlessa. Przypomina Szarota: „Wszyscy mieszkali razem w internacie, co w dużej mierze izolowało uczniów od bieżącego życia społecznego i politycznego. Z zasady nie czytało się tam gazet. Ich całym kosmosem stawał się na kilka lat trochę odrealniony świat Theresianum". (Szarota 2013, 179)

Jednym z bohaterów książki Piotra Szaroty jest także wiedeński Prater, park położony między Dunajem a kanałem naddunajskim, otwarty w roku 1766. Pod koniec XIX wieku zachodni kraniec Prateru - jak pisze autor Wiednia 1913 - przekształcił się w wielkie wesołe miasteczko. I dodaje:

Największą dumą wiedeńczyków był gigantyczny diabelski młyn z trzydziestoma gondolami, czyli Wiener Riesenrad. Został uruchomiony w 1897, dla uczczenia pięćdziesiątej rocznicy koronacji cesarza. Podobnie jak wieża Eiffla, Riesenrad stał 
się ukoronowaniem wieku żelaza i prawdziwie nowoczesnym symbolem miasta. Rittner pisze o nim z ogromnym przejęciem w jednym ze swoich felietonów: „A nad wszystkim wznosi się jakieś czarodziejskie, świetlane i ruszające się naokoło swej osi koło na czarnym niebie - „Riesenrad”, wielka zabawka dla dzieci, a tak imponująca w swych olbrzymich rozmiarach i w swej zuchwałej konstrukcji technicznej, że zrosła się (...) z panoramą miasta, widoku Wiednia nie można sobie bez tej „wielkiej zabawki” tak samo wyobrazić jak bez kościoła św. Szczepana albo bez Kahlenbergu. Góruje nad wszystkim niby symbol tego miasta, w którym życie wydaje się być tylko „zabawką” (Szarota 2013, 239, podkreśl. KKK).

Franz Kafka, prażanin, który może najbardziej przeczuł pełną przyszłej grozy beztroskę Wiednia, nie polubił tego miasta, odwiedzonego z konieczności, podczas podróży służbowej. Szarota przypomina: „Trzynastego września wieczorem zanotował z rezygnacją: „Byłoby najlepiej, gdybym te dni w Wiedniu mógł uczynić niebyłymi - i to od samego korzenia. Jutro rano o 8.45 wyjeżdżam do Triestu” (Szarota 2013, 242). A Triest to już „mała Wenecja", inny świat.

Wiedeń tuż przed I wojną światową to także swego rodzaju antycypacja tragicznych losów Żydów w tej części Europy (w samym Wiedniu co dziesiąty mieszkaniec był Żydem: wśród nich tacy jak Weininger, cierpiący na samo-nienawiść, Freud - „niewierzący Żyd”, czujący się dziedzicem kultury niemieckiej, Herzl - twórca syjonizmu, a obok niego antysyjonista, Joseph Roth, który przyrównuje syjonizm do nazizmu). 8 września 1913 roku odbywa się w naddunajskiej stolicy cesarstwa XI Kongres Syjonistyczny, gości na nim córka Theodora Herzla. A przecież Kafka, który również tam zajrzał, notuje: „Co mam wspólnego z Żydami? Ledwie coś wspólnego mam z sobą samym" (Szarota 2013, 243). Wielu Żydów tej części kontynentu to przecież Żydzi zasymilowani, posługują się językami społeczeństw, w których żyją (dla Franza Kafki czy Martina Bubera to była niemczyzna albo/i polszczyzna), mówią też i często piszą w jidysz, niestety przez wielu mieszkańców Środkowej Europy pogardliwie określanym jako „żargon”.

Szarota literacko korzysta z wiedeńskiego nadmiaru roku 1913, czerpie zeń pełnymi garściami. Nie stroni od anegdot, opisuje romanse i mezalianse. Przytacza aforyzm zakochanego beznadziejnie w Sidonie Nadherny von Borutin, arystokratce, posiadaczce zamku w Janowitz, przyjaciółce Rilkego - Karla Krausa, redaktora słynnej „Die Fackel”: „Każde małżeństwo jest mezaliansem" (Szarota 2013, 261). Ale nie zapomina o ironii losu opisywanej generacji: „XXI Konferencja Pokojowa została zaplanowana na sierpień 1914. Można powiedzieć, że to faktycznie trafiona data" (Szarota 2013, 271).

Kobiety w Wiedniu findesieclowym nie tylko się prostytuują („mężczyźni korzystają z usług prostytutek masowo i bez zażenowania"; Szarota 2013, 278) - w mieszczańskim świecie takie są standardy, regulujące męski seks przed- i pozamałżeński. Kobiety się także - przeciw normom asymetrii w wolności ciała - emancypują. Należy do nich Rosa Mayreder, 
której feministyczna dwutomowa Zur Kritik der Weiblichkeit ukazuje się w 1913 roku po angielsku. Jest prekursorką myślenia o płci w kategoriach ról kulturowych, wyprzedza o trzydzieści lat Margaret Mead. Sto lat temu w Wiedniu rozpoczyna się genderowe postrzeganie świata obu płci! A jednocześnie w tym samym Wiedniu, w tym samym czasie bestsellerem jest mizoginistyczny Weininger (popełniający teatralne samobójstwo 4 października 1903 roku), z którym pre-genderystka polemizuje. Wszystko się w gościnnym Wiedniu, a jakże, zmieściło.

Bismarck obawiał się, że Europa popełni samobójstwo ze strachu przed śmiercią. I tak się trochę stało. Oto ostatni akapit książki Piotra Szaroty - książki skłaniającej do wielu refleksji i drażniącej wyobraźnię, uśpioną złudzeniem, że nie żyjemy „przed”, tylko „po”:

Sylwestrowy wieczór 1908 roku w Café Central sportretował Lew Trocki w felietonie dla „Kijevskoj Mysli”. Pisał o grupce austriackich parlamentarzystów bardziej zaabsorbowanych grą w karty niż przesuwającymi się nieubłaganie wskazówkami zegara, o dziennikarzach flirtujących z wydekoltowanymi damami i o przekrzykujących się rosyjskich emigrantach. Potworny tłok, zabiegani kelnerzy roznoszący wino, poncz i grog, głośne wybuchy śmiechu i powtarzające się raz po raz radosne okrzyki: Prosit Neujahr!

Teraz, w ostatni dzień 1913 roku musiało być podobnie, z tą tylko różnicą, że na balach królowało tango, które w cień usunęło wiedeńskie walce. Choć ten nieznany dotąd egzotyczny taniec uchodził za skandalicznie rozerotyzowany, stary cesarz wielkodusznie pozwolił poddanym oddawać się tej rozpuście, chyba że ktoś nosił mundur c. k. armii. Szkoda, bo akurat żołnierzom przydałaby się ta rozpusta przed wymarszem na Wielką Rzeź (Szarota 2013, 352).

\section{Bibliografia:}

Appelfeld Aharon, 2004, Badenheim 1939, Szafir H. (przeł.), Warszawa.

Davies Norman, 1999, Europa. Rozprawa historyka z historia,

Tabakowska E. (przeł.), Kraków.

Herbert Zbigniew, 2000, Labirynt nad morzem, Warszawa.

Herbert Zbigniew, 2008, Wiersze zebrane, Krynicki R. (oprac. edytorskie), Kraków.

Kłańska Maria, 1991, Daleko od Wiednia. Galicja w oczach pisarzy niemieckojęzycznych 1772-1918, Kraków

Kuryluk Ewa, 1999, Wiedeńska apokalipsa. Eseje o kulturze austriackiej XX wieku, Warszawa.

Patočka Jan, 1998, Eseje heretyckie z filozofii dziejów, Czcibor-Piotrowski A., Szczepańska E., Zychowicz J. (przeł.), Warszawa.

Stern Fritz, 2001, Niemiecki świat Einsteina. Eseje o historii Niemiec XX wieku, tłum. różni, Gałecki Ł. (wybór), Warszawa.

Szewc Piotr, 1987, Zagłada, Warszawa. 
Szarota Piotr, 2013, Wiedeń 1913, Gdańsk.

Wiegandt Ewa, 1988, Austria felix, czyli o micie Galicji w polskiej prozie współczesnej, Poznań.

Wiegandt Ewa, 2010, Niepokoje literatury. Studia o prozie polskiej XX wieku, Poznań.

\section{O Autorce:}

Katarzyna Kuczyńska-Koschany, prof. UAM dr hab., polonistka, komparatystka, eseistka, prozaik. Autorka książek: Rilke poetów polskich (2004; w druku wydanie II), Rycerz i Śmierć. O „Elegiach duinejskich” Rainera Marii Rilkego (2010; wyd. II, e-book, 2015), Interlinie w ciemności. Jednak interpretacja (2012), „Wsje poety Żydy”. Antytotalitarne gesty poetyckie i kreacyjne wobec Zagłady oraz innych doświadczeń granicznych (2013), tomu prozy Zielony promień (2006), współautorka podręcznika Staropolskie korzenie współczesności (2004). Członkini Rady Programowej „Miasteczka Poznań, Rady Naukowej „Narracji o Zagładzie”, Zespołu Badań nad Literaturą Zagłady IBL PAN, Komitetu Nauk o Literaturze PAN (kadencja 2015-2018), stowarzyszenia Otwarta Rzeczpospolita. Opiekunka Koła Naukowego Miłośników Kultury i Literatury Żydowskiej „Dabru emet” na UAM. 